\title{
Some bovine proteins behave as dietary fibres and reduce serum lipids in rats
}

\author{
Liyanage Ruvini ${ }^{1}$, Naoto Hashimoto ${ }^{1}$, Kyu-Ho Han $^{1}$, Teppei Kajiura ${ }^{1}$, Shoko Watanabe ${ }^{1}$, \\ Ken-ichiro Shimada ${ }^{1}$, Mitsuo Sekikawa ${ }^{1}$, Kiyoshi Ohba ${ }^{2}$ and Michihiro Fukushima ${ }^{1}{ }^{*}$ \\ ${ }^{1}$ Department of Animal Science, Obihiro University of Agriculture and Veterinary Medicine, Obihiro, Hokkaido 080-8555, Japan \\ ${ }^{2}$ Hokkaido Tokachi Area Regional Food Processing Technology Center, Obihiro, Hokkaido 080-2462, Japan
}

(Received 6 June 2006 - Revised 10 November 2006 - Accepted 24 November 2006)

\begin{abstract}
We examined the physiological importance of bovine dietary proteins in rats fed diets prepared from bovine Achilles' tendons and arteries. Rats were fed for 4 weeks, with a $20 \%$ casein diet (CON), in comparison with two diets containing $15 \%$ casein and $5 \%$ of either bovine Achilles' tendon (AC) or artery (AR) protein preparations. The serum total cholesterol concentration and non-HDL-cholesterol level in the AR-fed group were significantly lower $(P<0.05)$ than those in the CON-fed group at the end of the 4-week feeding period. The hepatic mRNA were measured, and the hydroxyl methyl glutaryl-CoA reductase mRNA level was significantly lower $(P<0.05)$ in the AR-fed group compared with the CON-fed group. Total hepatic cholesterol concentration in AC-fed rats was significantly $(P<0 \cdot 05)$ higher than in the CON-fed group. The serum TAG concentration and fatty acid synthase mRNA level in AC- and AR-fed groups were significantly lower $(P<0 \cdot 05)$ compared with the CON-fed group throughout the feeding period. Faecal neutral sterol excretion was significantly $(P<0 \cdot 05)$ higher in the AC- and AR-fed groups compared with the CON-fed group. The results of the present study demonstrate that some bovine dietary proteins have similar functions as dietary fibres, lowering serum lipid concentration by enhancing faecal neutral sterol excretion or suppressing lipid synthesis in the liver. Moreover, favourable amino acid compositions in the AR and AC preparations may also have a lowering effect on plasma lipid concentration in bovine protein diet-fed groups.
\end{abstract}

Bovine dietary protein: Serum lipids: Dietary fibres: Hepatic messenger ribonucleic acids

At present there is an increasing interest in the capacity of food and food components to reduce the risk of non-infectious diseases related to diet. Dietary fibres have gained a considerable interest due to their favourable health effects. According to recent studies it has been proven that dietary fibre intake is inversely correlated with several CVD factors, which supports its protective role against cardiovascular diseases and recommendations for its increased consumption (Lairon et al. 2005; Erkkila \& Lichtenstein, 2006).

From past studies it has been shown that some plant fibres have a hypocholesterolaemic effect, which may be due to fibre-induced alterations of intestinal absorption, intestinal or pancreatic hormone secretion, lipoprotein metabolism, bile acid metabolism, or fermentation by-products and their effects on hepatic cholesterol synthesis (Kay, 1982). When animal dietary fibres are concerned, relatively few studies have been carried out to investigate the effect on lipid metabolism. Normally, it is believed that those who are at risk of CHD should consume less red meat due to adverse health impacts.

Bovine Achilles' tendons and arteries are waste products of the beef industry that could be used as a potential source of functional protein for possible food applications due to their favourable amino acid composition and indigestible behaviour.
This hypothesis may be supported by previous findings showing that dietary proteins with favourable amino acid composition reduced serum cholesterol level in rats (Morita et al. 1997; Gudbrandsen et al. 2005). The indigestible behaviour of animal protein may be due to the abundant collagen concentration, as Achilles' tendons and artery protein contain high glycine and proline concentrations (Schubert et al. 1974). In the present study, we investigated the effect of some bovine dietary proteins on serum lipids, liver lipids, faecal lipids, bacterial population in the colon, and hepatic mRNA in rats.

\section{Experimental methods}

Animals and diets

Male Crj/Wistar rats (5 weeks old) were purchased from Charles River Japan Inc. (Yokohama, Japan). They were housed individually in cages with free access to food and water. The animal facility was maintained on a $12 \mathrm{~h}$ lightdark cycle at a temperature of $23 \pm 1{ }^{\circ} \mathrm{C}$ and relative humidity of $60 \pm 5 \%$. The rats were randomly assigned to three groups (n 5). There were no significant differences in body weight and serum total cholesterol concentration among groups at

Abbreviations: AC, bovine Achilles' tendon diet; AR, bovine artery diet; CON, casein diet; CYP7A1, cholesterol 7 $\alpha$-hydroxylase; FAS, fatty acid synthase; GAPDH, glyceraldehyde-3-phosphate dehydrogenase; HMG, hydroxyl methyl glutaryl; LDL-R, LDL receptor; SR-B1, scavenger receptor type B1; SREBP-1c, sterol regulatory element binding protein-1c.

* Corresponding author: Dr Michihiro Fukushima, fax +81 15549 5577, email fukushim@obihiro.ac.jp 
the beginning of the experiment. The composition of each diet is shown in Table 1. The experimental rats were fed for 4 weeks, with a $20 \%$ casein diet (CON), in comparison with two diets containing $15 \%$ casein and $5 \%$ of either bovine Achilles' tendons (AC) or artery (AR) protein preparations. The AC and AR proteins were prepared as follows; first, raw bovine Achilles' tendons and arteries were defatted by washing and then boiling for $2 \mathrm{~h}$. The boiled Achilles' tendons and arteries were freeze-dried and milled at 300 mesh. The compositions of $\mathrm{AC}$ and $\mathrm{AR}$ were as follows (g/100g dry weight): moisture, 2.1 and 4.1 ; protein, 73.9 and $81 \cdot 0$; lipid, 23.1 and 8.4; carbohydrate, 0.5 and 5.9; ash, 0.4 and 0.6 , respectively. Total moisture, protein, lipid and carbohydrate content were determined by the procedure of the Association of Official Analytical Chemists (1990). Dietary cholesterol level in the $\mathrm{AC}$ and $\mathrm{AR}$ was determined ( $\mathrm{g} / \mathrm{kg}$ diet), and it was $0.1(0.01 \%)$ and $0.06(0.006 \%)$, respectively. The control group consisted of rats fed $200 \mathrm{~g}$ casein $/ \mathrm{kg}$. The amino acid compositions of the AC, AR and $\mathrm{CON}$ are shown in Table 2. The amino acid compositions were determined as follows; first $4 \mathrm{mg}$ of $\mathrm{AC}$ and AR samples were hydrolysed in $2 \mathrm{ml}$ of $6 \mathrm{M}-\mathrm{HCl}$ at $110^{\circ} \mathrm{C}$ for $24 \mathrm{~h}$, vacuum dried and then reconstituted with $1 \mathrm{ml}$ of $0.2 \mathrm{M}-\mathrm{HCl}$, filtered with $0.45 \mu \mathrm{m}$ diameter filter (W-13-5; Tosoh, Tokyo, Japan) and analysed with a Hitachi-8700 amino acid analyzer (Hitachi Ltd, Tokyo, Japan). The rats were allowed free access to food and water for 4 weeks. Body weight and food consumption were recorded weekly and daily, respectively. This experimental design was approved by the Animal Experiment Committee of Obihiro University of Agriculture and Veterinary Medicine. All animal procedures conformed to standard principles described in Guide for the Care and Use of Laboratory Animals (National Research Council, 1985).

\section{Analytical procedures}

Blood samples $(1 \mathrm{ml})$ were collected between 08.00 and 10.00 hours from the jugular veins of fasting rats anaesthetised by sodium pentobarbital. The samples were taken into tubes without an anticoagulant. After the samples were allowed to stand

Table 1. Composition of the experimental diets ( $\mathrm{g} / \mathrm{kg}$ diet)

\begin{tabular}{lccc}
\hline & \multicolumn{3}{c}{ Dietary group } \\
\cline { 2 - 4 } Ingredients & CON & AC & AR \\
\hline Casein & 200 & 150 & 150 \\
Bovine Achilles' tendon protein & - & $50^{*}$ & - \\
Bovine artery protein & - & - & $50 \dagger$ \\
Soyabean oil & 70 & 70 & 70 \\
AIN-93G mineral mixture & 35 & 35 & 35 \\
AIN-93G vitamin mixture & 10 & 10 & 10 \\
Cellulose powder & 50 & 50 & 50 \\
Sucrose & 100 & 100 & 100 \\
L-Cystine & 3 & 3 & 3 \\
Choline hydrogen tartrate & 2.5 & 2.5 & 2.5 \\
3-Butylhydroquinone & 0.014 & 0.014 & 0.014 \\
$\alpha$-Maize starch & 529.486 & 529.486 & 529.486 \\
\hline
\end{tabular}

CON, casein control diet; AC, bovine Achilles' tendon diet; AR, bovine artery diet. ${ }^{\star}$ Cholesterol $0.1 \mathrm{~g} / \mathrm{kg}$ diet.

† Cholesterol $0.06 \mathrm{~g} / \mathrm{kg}$ diet. at room temperature for $2 \mathrm{~h}$, the sera were separated by centrifugation at $1500 \mathrm{~g}$ for $20 \mathrm{~min}$. All faecal excretions were collected during the last $3 \mathrm{~d}$ of the experimental period (4 weeks). Faecal dry weight did not differ among groups. The rats were killed by diethyl ether inhalation, and the livers and caecum quickly removed, washed with cold saline $(9 \mathrm{~g}$ $\mathrm{NaCl} / \mathrm{l}$ ), blotted dry on filter paper, and weighed before freezing for storage.

\section{Chemical analysis}

Total cholesterol, HDL-cholesterol, and TAG concentrations in the serum were determined enzymically using commercially available reagent kits (assay kits for the TDX system; Abbott Laboratory Co., Irving, TX, USA). The non-HDLcholesterol concentration was calculated as follows: nonHDL-cholesterol $=$ total cholesterol - HDL-cholesterol.

Total lipids were extracted from liver and faeces by a mixture of chloroform-methanol (2:1, v/v) (Folch et al. 1957). The neutral steroids in each lipid sample obtained by saponification were acetylated (Matsubara et al. 1990) and analysed by GLC using a Shimadzu 14A chromatograph (Kyoto, Japan) with a DB17 capillary column $(0.25 \mathrm{~mm} \times 30 \mathrm{~m}$; J\&W Scientific, Folsom, CA, USA) with $\mathrm{N}_{2}$ as the carrier gas. Acidic sterols in faeces were measured by GLC following the method of Grundy et al. (1965). Sterol balance was calculated as sterol balance $=$ (faecal cholesterol + faecal coprostanol + faecal bile acids) - dietary cholesterol intake. A part of the caecal content was taken out into desalting water in a vial without exposure to air, and suspended. The suspension of caecum was deproteinised with perchloric acid and to form $\mathrm{Na}$ salts of the SCFA. Individual SCFA were measured by GLC with a glass column $(2000 \times 3 \mathrm{~mm})$ packed with 80-100 mesh chromosorb W-AW DMCS with $\mathrm{H}_{3} \mathrm{PO}_{4}(100 \mathrm{ml} / \mathrm{l})$ as the liquid phase after adding $\mathrm{H}_{3} \mathrm{PO}_{4}$ according to the procedure of Hara et al. (1994). Faecal $\mathrm{N}$ content was determined by Kjeldahl's method. Apparent digestibility of protein was calculated as apparent protein digestibility $=$ (protein intake - faecal protein) $/$ protein intake $\times 100$.

Ribonucleic acid isolation, reverse transcription-polymerase chain reaction and Southern blot analysis

Total RNA was isolated from the liver by the acid guanidiumphenol-choloroform method using Isogen (Nippon Gene, Tokyo, Japan; Chomczynski \& Sacchi, 1987). mRNA encoding the LDL receptor (LDL-R), cholesterol 7 $\alpha$-hydroxylase (CYP7A1), fatty acid synthase (FAS), hydroxyl methyl glutaryl (HMG)-CoA reductase, scavenger receptor type B1 (SR-B1), sterol regulatory elementary binding protein (SREBP-1c), and glyceraldehyde-3-phosphate dehydrogenase (GAPDH; used as an invariant control) were analysed by semi-quantitative RTPCR and subsequent Southern hybridisation of the PCR products with each inner oligonucleotide probe. Total RNA samples were treated with DNase RQ1 (Promega, Madison, WI, USA) to remove genomic DNA and subjected to RT-PCR by using Moloney murine leukaemia virus RT (Gibco-BRL, Gaithersburg, MD, USA) and EX-Taq polymerase (Takara, Tokyo, Japan) with LDL-R primers of oligonucleotides (upstream primer, 5'-ATTTTGGAGGATGAGAAGCAG-3'; downstream primer, 
Table 2. Amino acid composition of bovine proteins (mmol/g nitrogen)

\begin{tabular}{lrrr}
\hline Amino acid & CON & AC & AR \\
\hline Asp & 6.75 & 6.78 & 4.85 \\
Thr & 4.43 & 2.69 & 2.82 \\
Ser & 6.24 & 4.79 & 3.63 \\
Glu & 18.42 & 10.72 & 7.57 \\
Gly & 3.04 & 33.30 & 30.04 \\
Cys & 0.26 & 0.14 & 0.49 \\
Val & 7.31 & 3.43 & 10.27 \\
Met & 2.48 & 0.76 & 0.56 \\
lle & 5.32 & 2.08 & 3.67 \\
Leu & 9.13 & 4.69 & 8.20 \\
Tyr & 3.93 & 0.95 & 2.60 \\
Phe & 3.88 & 2.17 & 3.61 \\
Lys & 6.92 & 3.21 & 2.95 \\
His & 2.48 & 0.92 & 0.88 \\
Arg & 2.70 & 7.14 & 3.75 \\
Ala & 4.32 & - & - \\
Pro & 12.39 & 16.24 & 14.09 \\
\hline CON, casein; AC, bovine Achilles' tendon powder; AR, bovine \\
artery powder.
\end{tabular}

5'-CAGGGCGGGGAGTGTGAGAA-3'), CYP7A1 primers of oligonucleotides (upstream primer, 5'-GCCGTCCAAGAAATCAAGCAGT-3'; downstream primer, 5'-TGTGGGCAGCGAGAACAAAGT- $3^{\prime}$ ), FAS primers of oligonucleotides (upstream primer, 5'-GCTGGAGCCCCTTTTTGTCTT-3'; downstream primer, 5'-ACCCCAGCACTGCAGTTTTCT-3'), HMG-CoA reductase primers of oligonucleotides (upstream primer, $5^{\prime}$ GCGTGCAAAGACAATCCTGGAG-3'; downstream primer, 5'-GTTAGACCTTGAGAACCCAATG-3'), SR-B1 primers of oligonucleotides (upstream primer, 5'-GTAGGGCCCAGAAGACACCAC- $3^{\prime}$; downstream primer, $5^{\prime}$-CGCCTGCTTCACCACCTTCTT- $3^{\prime}$ ), SREBP-1c primers of oligonucleotides (upstream primer, 5'-GAGCCACAATGAAGACCGCA-3'; downstream primer, 5'-CAAGGACAAGGGGCTACTCT-3') and GAPDH primers of oligonucleotides (upstream primer, 5'-GCCATCAACGACCCCTTCATT-3'; downstream primer, $5^{\prime}$-CGCCTGCTTCACCACCTTCTT-3'). The reaction mixtures for the PCR contained $25 \mathrm{pmol}$ of each primer, $1.25 \mathrm{U}$ of EX-Taq polymerase, 1x PCR buffer (Takara), and $200 \mu \mathrm{M}$ dNTP in a $50 \mu 1$ reaction volume. Temperature cycling was as follows: first cycle, denaturation at $94^{\circ} \mathrm{C}$ for $3 \mathrm{~min}$, annealing at $60^{\circ} \mathrm{C}$ for $1 \mathrm{~min}$, and extension at $72^{\circ} \mathrm{C}$ for $2 \mathrm{~min}$. Subsequent cycles were denaturation at $94^{\circ} \mathrm{C}$ for $1 \mathrm{~min}$, annealing at $60^{\circ} \mathrm{C}$ for $1 \mathrm{~min}$, and extension at $72^{\circ} \mathrm{C}$ for $2 \mathrm{~min}$. The thermal cycling was completed by terminal extension at $72^{\circ} \mathrm{C}$ for $10 \mathrm{~min}$. In total, twenty-five cycles were performed for LDL-R and CYP7A1, thirty cycles for HMG-CoA reductase and SR-B1, and twenty cycles for FAS, GAPDH and SREBP-1c. Amplification products were electrophoresed on $2 \%$ agarose gel and transferred to a nylon membrane (Biodyne B; Pall Bio-Support, East Hills, NY, USA). Blots were hybridised with an LDL-R probe of a fifty-four-base oligonucleotide (5'-CCAGGGTTGGTCGCTTTGCCCTGGAGCTGATCTGTCACCTCCAGCTCTCCCTC- $\left.3^{\prime}\right)$, CYP7A1 probe of a fifty-four-base oligonucleotide $\left(5^{\prime}-\right.$ CCCGAAGGCCTGTTTAAGTGATGACTCTCAGCCGCCAAGTGACATCATCCAGTG-3'), FAS receptor probe of a fiftyfour-base oligonucleotide (5'-CTGCTCTCTGTGGATAGGACTGAATGCTGTGGCCTTCTGATAGACTCTTCTGGA-3'), HMG-CoA reductase probe of a fifty-four-base oligonucleotide
(5'-GATCTGTTGTGAACCATGTGACTTCTGACAAGATGTCCTGCTGCCAATGCTGCC-3'), SR-B1 probe of a fiftyfour-base oligonucleotide (5'-TGCCGTGTGGACAGTGTGACATCTTGGGGCTCAGGACGTGGCACTGGCGGGTTG$\left.3^{\prime}\right)$, SREBP-1c probe of a fifty-four-base oligonucleotide $\left(5^{\prime}\right.$ GCCGGCGTCTGAGGGTGGAGGGGTCAGCGTTTCTACCACTTCAGGTTTCATGCC-3') and GAPDH probe of a fiftyfour-base oligonucleotide ( $5^{\prime}$-TGATGACCAGCTTCCCATTCTCAGCCTTGACTGTGCCGTTGAACTTGCCGTGGG-3'). The probe was $3^{\prime}$-tailing labelled with digoxigenin, using a DIG oligonucleotide tailing kit (Boehringer Mannheim, Mannheim, Germany). Prehybridisation, hybridisation, and detection were carried out with a DIG luminescent detection kit (Boehringer Mannheim) as recommended by the manufacturer. The relative quantity of mRNA was estimated by densitometry scanning with X-ray film.

\section{Growth of bacteria in the caecum}

Coliforms in the caecum were inoculated and grown for $2 \mathrm{~d}$ on DHL agar (Eiken Chemical Co. Ltd, Tokyo, Japan) plates at $37^{\circ} \mathrm{C}$. Anaerobes, Lactobacillus and Bifidobacterium in the caecum were incubated for $5 \mathrm{~d}$ on GAM agar (Nissui Pharmaceutical Co. Ltd, Tokyo, Japan), Rogosa agar (Merck KGaA, Darmstadt, Germany) and BL agar (Eiken Chemical Co. Ltd, Tokyo, Japan) at $37^{\circ} \mathrm{C}$ by the gaspak method according to the procedure of Mitsuoka et al. (1964, 1965, 1976).

\section{Statistical analysis}

Data are presented as means and standard deviations for serum total cholesterol, HDL-cholesterol and non-HDL-cholesterol at prescribed times. The significance of differences among treatment groups was determined by ANOVA with Duncan's multiple range test and Student's $t$ test (SAS Institute, Cary, NC, USA). Differences were considered significant at $P<0 \cdot 05$.

Results

There was no significant difference in the food intake, bodyweight gain, liver weight, caecum weight, faecal dry weight and caecal $\mathrm{pH}$ among groups at the end of the experimental period (data not shown). The apparent digestibility of AC and AR was about 92-93\%, which was lower than CON (96\%).

Table 3 shows the serum total cholesterol, non-HDL-cholesterol, HDL-cholesterol and TAG concentrations of rats. The serum total cholesterol and non-HDL-cholesterol concentration in the AR-fed group were significantly lower than the CON group at the end of the 4-week feeding period. There was no significant difference in the HDL-cholesterol concentration among the groups. The serum TAG concentration was significantly lower in the AC- and AR-fed groups than that in the CON group through out the feeding period. The liver cholesterol concentrations in rats at the end of the experimental period are shown in Fig. 1. The liver cholesterol concentration in rats fed $\mathrm{AC}$ was significantly higher than in the CON group at the end of the 4-week feeding period.

Table 4 shows the dietary cholesterol intake, faecal neutral steroid and acidic steroid concentrations of rats. The bovine dietary cholesterol intake in rats fed the $\mathrm{AC}$ and $\mathrm{AR}$ diets were 7.20 (SD 1.03) and 6.91 (SD 0.61) $\mu \mathrm{mol} / \mathrm{rat}$ per $\mathrm{d}$, respectively. The faecal neutral sterol excretion was 
Table 3. Serum total cholesterol, high-density-lipoprotein-cholesterol, very-low-density-lipoprotein-cholesterol + intermediate-density-lipoprotein-cholesterol + low-density-lipoprotein-cholesterol, and triacylglycerol concentrations in rats fed bovine proteins for 4 weeks $(\mathrm{mmol} / \mathrm{l})$

(Mean values and standard deviations for five rats)

\begin{tabular}{|c|c|c|c|c|c|c|}
\hline \multirow[b]{2}{*}{ Dietary group } & \multicolumn{2}{|c|}{ Week 0} & \multicolumn{2}{|c|}{ Week 2} & \multicolumn{2}{|c|}{ Week 4} \\
\hline & Mean & SD & Mean & SD & Mean & SD \\
\hline \multicolumn{7}{|c|}{ Total cholesterol } \\
\hline CON & $2 \cdot 51$ & 0.15 & $2.53^{\mathrm{a}}$ & 0.26 & $2 \cdot 29$ & 0.209 \\
\hline AC & $2 \cdot 37$ & 0.42 & $2 \cdot 16^{a, b}$ & 0.34 & 1.99 & 0.433 \\
\hline AR & $2 \cdot 46$ & 0.14 & $2.08^{\mathrm{b}}$ & 0.30 & $1.94^{*}$ & 0.248 \\
\hline \multicolumn{7}{|c|}{ HDL-cholesterol } \\
\hline CON & 0.77 & 0.02 & 0.72 & $0 \cdot 10$ & 0.69 & 0.08 \\
\hline$A C$ & 0.75 & $0 \cdot 15$ & 0.68 & 0.13 & 0.66 & 0.14 \\
\hline$A R$ & 0.76 & 0.05 & 0.64 & $0 \cdot 10$ & 0.64 & 0.08 \\
\hline \multicolumn{7}{|c|}{ non-HDL-cholesterol } \\
\hline CON & 1.75 & $0 \cdot 13$ & $1 \cdot 81^{\mathrm{a}}$ & $0 \cdot 18$ & 1.59 & $0 \cdot 16$ \\
\hline$A C$ & 1.62 & 0.29 & $1.47^{\mathrm{b}}$ & 0.25 & 1.33 & 0.31 \\
\hline AR & 1.70 & 0.14 & $1.45^{\mathrm{b}}$ & 0.24 & $1 \cdot 31^{*}$ & 0.19 \\
\hline \multicolumn{7}{|l|}{ TAG } \\
\hline CON & 0.42 & 0.15 & $0.85^{\mathrm{a}}$ & 0.24 & $0.76^{\mathrm{a}}$ & 0.17 \\
\hline $\mathrm{AC}$ & 0.34 & $0 \cdot 16$ & $0.44^{\mathrm{b}}$ & 0.12 & $0.35^{\mathrm{b}}$ & 0.16 \\
\hline AR & 0.39 & 0.07 & $0.52^{\mathrm{b}}$ & 0.08 & $0.37^{\mathrm{b}}$ & 0.16 \\
\hline
\end{tabular}

CON, casein control diet; AC, bovine Achilles' tendon diet; AR, bovine artery diet.

$\mathrm{a}, \mathrm{b}$ Mean values within a column with unlike superscript letters were significantly different $(P<0.05)$ (Duncan's multiple range test).

${ }^{\star} P<0.05$ v. CON by Student's $t$ test.

significantly higher in the AC- and AR-fed groups than those in the CON group, and those in the AC-fed group were the highest among all the groups. However, the data on faecal coprostanone level are lacking in Table 4 due to unavailability. Further, there were no significant differences in total bile acid, cholic acid, chenoceoxycholic acid, deoxycholic acid and lithocholic acid concentrations among the groups. Sterol balance in rats fed CON, AC and AR were 14.64, 26.96 and $14.16 \mu \mathrm{mol} / \mathrm{rat}$ per $\mathrm{d}$, respectively. There were no significant differences in total SCFA, acetic acid, propionic

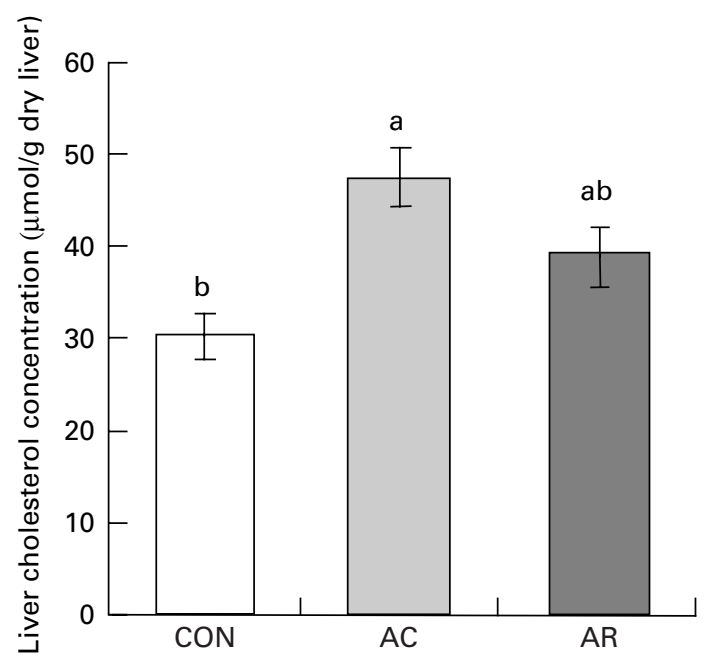

Fig. 1. Liver cholesterol concentration in rats fed animal proteins for 4 weeks. CON, casein diet; AC, bovine Achilles' tendon protein diet; AR, bovine artery protein diet. Values are means for five rats, with standard deviations represented by vertical bars. ${ }^{a, b}$ Mean values with unlike letters were significantly different $(P<0 \cdot 05)$.
Table 4. Cholesterol intake, and faecal neutral steroid and acidic steroid concentrations in rats fed bovine proteins for 4 weeks $(\mu \mathrm{mol} / \mathrm{rat}$ per $\mathrm{d}$ )

(Mean values and standard deviations for five rats)

\begin{tabular}{|c|c|c|c|c|c|c|}
\hline \multirow[t]{2}{*}{ Dietary group... } & \multicolumn{2}{|c|}{ CON } & \multicolumn{2}{|c|}{$\mathrm{AC}$} & \multicolumn{2}{|c|}{ AR } \\
\hline & Mean & SD & Mean & SD & Mean & SD \\
\hline Cholesterol intake & - & - & $7 \cdot 20$ & 1.03 & 6.91 & 0.61 \\
\hline Faecal cholesterol & $11 \cdot 62^{b}$ & 4.00 & $20 \cdot 69^{a}$ & 5.45 & $12 \cdot 65^{\mathrm{b}}$ & 1.72 \\
\hline Faecal coprostanol & $2 \cdot 20^{c}$ & 0.90 & $12 \cdot 69^{a}$ & 2.50 & $7 \cdot 88^{b}$ & 2.05 \\
\hline Faecal LCA & 0.14 & 0.07 & 0.13 & 0.01 & 0.12 & 0.03 \\
\hline Faecal DCA & 0.05 & 0.03 & 0.07 & 0.02 & 0.05 & 0.03 \\
\hline Faecal CDCA & 0.02 & 0.03 & 0.03 & 0.01 & 0.02 & 0.02 \\
\hline Faecal CA & 0.20 & 0.11 & 0.16 & $0 \cdot 20$ & 0.08 & 0.02 \\
\hline Faecal TBA & 0.41 & 0.23 & 0.39 & $0 \cdot 10$ & 0.27 & 0.04 \\
\hline
\end{tabular}

CON, casein control diet; AC, bovine Achilles' tendon diet; AR, bovine artery diet; LCA, lithocholic acid; DCA, deoxycholic acid; CDCA, chenodeoxycholic acid; CA, cholic acid; TBA, total bile acids.

a,b,c Mean values within a row with unlike superscript letters were significantly different $(P<0.05)$

acid and $n$-butyric acid excretions in the caecum among the three groups (data not shown).

The relative quantities of mRNA were determined by the Southern hybridisation of PCR-amplified LDL-R cDNA, CYP7A1 cDNA, HMG-CoA reductase cDNA, SR-B1 cDNA, SREBP-1c cDNA and FAS cDNA in the rat liver. The values of LDL-R, CYP7A1, HMG-CoA reductase, SRB1, SREBP-1c and FAS mRNA were normalised to 1.00. There was no significant difference in relative quantity of LDL-R mRNA among the three groups and the quantities for $\mathrm{CON}, \mathrm{AC}$ and $\mathrm{AR}$ were 0.856, 0.809 and 0.796 respectively. No significant difference was observed for the relative quantity of CYP7A1 mRNA among the three groups (Fig. 2). The relative quantity of hepatic $\mathrm{HMG}-\mathrm{CoA}$ reductase mRNA in the AR-fed group was significantly lower than in the CON group $(P<0.05)$, and that in the AC-fed group tended to be lower compared with the $\mathrm{CON}$ group (Fig. 2). The relative quantity of FAS mRNA level in the AC- and AR-fed groups was significantly lower than that in the CON group (Fig. 3). No significant difference was observed for the relative quantity of SR-B1 mRNA level, and the quantities for CON, AC and AR were 0.68, 0.67 and 0.66, respectively. The SREBP-1c mRNA level in the AR-fed group was significantly lower than that in the CON group, and that in the AC-fed group tended to be lower compared with the CON group (Fig. 3). The FAS mRNA level was positively correlated with SREBP-1c mRNA level $(r 0.660 ; P<0.01)$.

Table 5 shows the caecal bacterial population in rats. Anaerobe bacterial population was significantly higher in the AC- and AR-fed groups compared with the CON group. Bifidobacterium population in the AR-fed group was significantly higher compared with the CON group, and that in the AC-fed group tended to be elevated compared with the CON group. Coliform bacterial population was significantly higher in the AC-fed group compared with the CON group, and that in the AR-fed group tended to be elevated compared with the $\mathrm{CON}$ group.

\section{Discussion}

In the present study, we examined the effects of some bovine proteins on serum lipids, liver lipids, faecal lipids, caecal 
(A)

HMG-CoA reductase

GAPDH
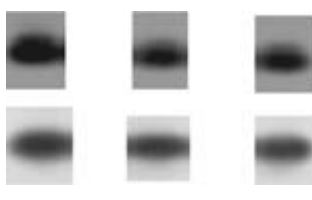

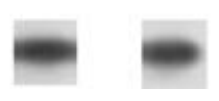

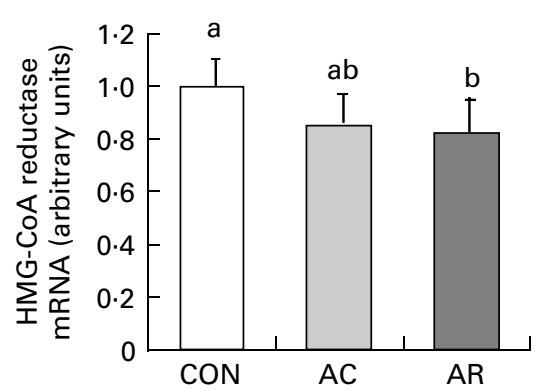

(B)

Cholesterol $7 \alpha-$ hydroxylase

GAPDH

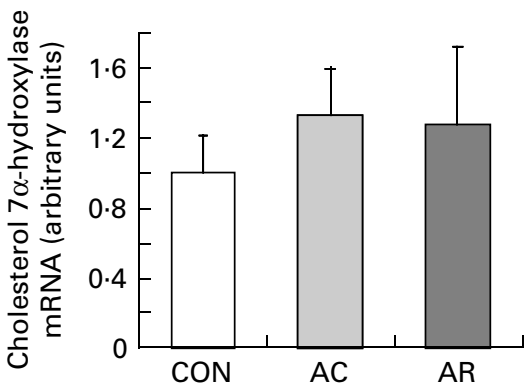

Fig. 2. Hepatic hydroxyl methyl glutaryl (HMG)-CoA reductase mRNA (A) and cholesterol $7 \alpha$-hydroxylase mRNA (B) expressions in rats fed animal proteins for 4 weeks. GAPDH, glyceraldehyde-3-phosphate dehydrogenase; CON, casein diet; AC, bovine Achilles' tendon protein diet; AR, bovine artery protein diet. Values are means for five rats, with standard deviations represented by vertical bars. ${ }^{\mathrm{a}, \mathrm{b}}$ Mean values with unlike letters were significantly different $(P<0.05)$.

lipids and bacterial population in the colon, and hepatic mRNA in rats. The serum total cholesterol and non-HDLcholesterol concentration in the AR-fed group were significantly lower than those in the CON group at the end of the 4-week feeding period. Several mechanisms may have caused these findings. One possible reason may be that bovine proteins act as dietary fibres. This could be supported by the lower digestibility of AC and AR (92-93\%) compared with CON (96\%). Jorgensen et al. (2003) have reported that increased intake of dietary fibre was associated with a concomitant loss of protein and energy to faeces. Previous findings have showed that dietary fibres lower plasma cholesterol levels in animals and human subjects compared with casein-based diets (Khosla et al. 1991; Anderson et al. 1995). The factor lowering the cholesterol concentration in the AR-fed group was the lowering of the non-HDL-cholesterol level, which was in agreement with previous findings
(Fukushima et al. 2000; Li et al. 2004). However, there was no significant difference in hepatic LDL-R mRNA level in rats fed bovine proteins compared with the $\mathrm{CON}$ group. Thus, the lower non-HDL-cholesterol concentration in the AR-fed group may be due to any other reason. This result was in agreement with previous findings showing that there was no correlation between plasma LDL-cholesterol concentration and hepatic LDL-R mRNA level (Sorci-Thomas et al. 1989). The CYP7A1 mRNA level and faecal bile acid concentration were not significantly different among the groups. The rate-limiting enzyme in endogenous sterol biosynthesis is HMG-CoA reductase, which catalyses the synthesis of mevalonate, and the activity of HMG-CoA reductase is also regulated by changes in the exogenous cholesterol concentration (Brown \& Goldstein, 1997). In the present experiment, HMG-CoA reductase mRNA expression was significantly lower in the AR-fed group, and tended to be lower in the
(A)

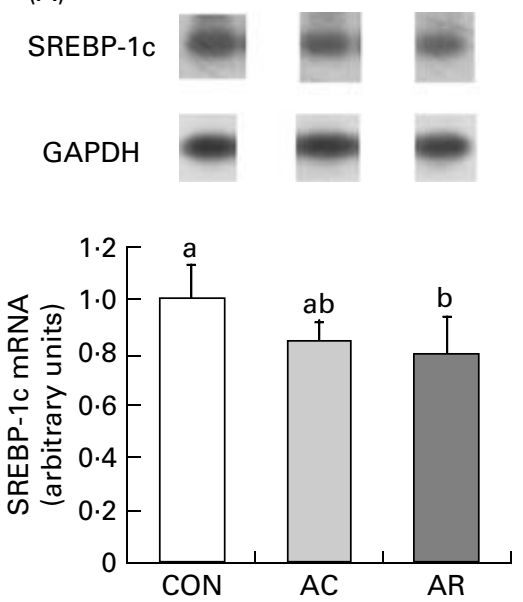

(B)
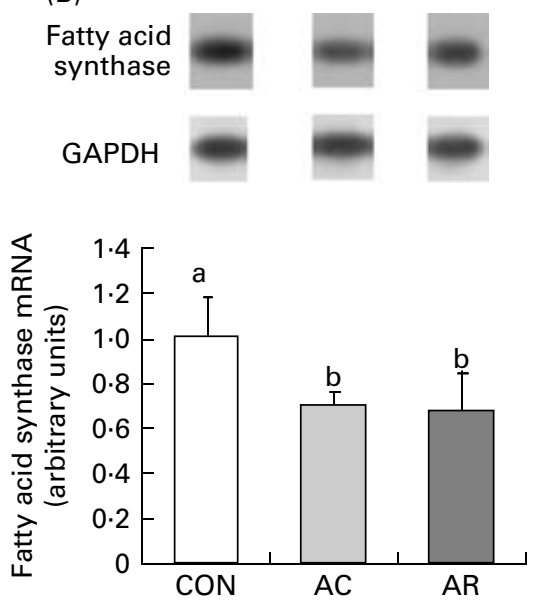

Fig. 3. Hepatic sterol regulatory element binding protein-1c (SREBP-1c) (A) and fatty acid synthase mRNA (B) expressions in rats fed animal proteins for 4 weeks. GAPDH, glyceraldehyde-3-phosphate dehydrogenase; CON, casein diet; AC, bovine Achilles' tendon protein diet; AR, bovine artery protein diet. Values are means for five rats, with standard deviations represented by vertical bars. ${ }^{\mathrm{a}, \mathrm{b}}$ Mean values with unlike letters were significantly different $(P<0.05)$. 
Table 5. Caecal bacterial populations in rats fed bovine proteins for 4 weeks $\left(\log _{10} \mathrm{cfu} /\right.$ wet $\left.\mathrm{g}\right)$

(Mean values and standard deviations for five rats)

\begin{tabular}{|c|c|c|c|c|c|c|}
\hline \multirow[t]{2}{*}{ Dietary group... } & \multicolumn{2}{|c|}{ CON } & \multicolumn{2}{|c|}{$A C$} & \multicolumn{2}{|c|}{ SR } \\
\hline & Mean & SD & Mean & SD & Mean & SD \\
\hline Bifidobacterium & $5.97^{\mathrm{b}}$ & 0.83 & $6 \cdot 30^{\mathrm{a}, \mathrm{b}}$ & 0.49 & $6 \cdot 65^{\mathrm{a}}$ & 0.32 \\
\hline Lactobacillus & $5.73^{a}$ & 0.64 & $6 \cdot 12^{\mathrm{a}}$ & 0.61 & $5 \cdot 67^{\mathrm{a}}$ & 0.83 \\
\hline Coliforms & $3.91^{b}$ & 0.35 & $4.91^{\mathrm{a}}$ & $1 \cdot 36$ & $4 \cdot 61^{a, b}$ & 0.79 \\
\hline Anaerobes & $6 \cdot 84^{b}$ & 0.33 & $7 \cdot 48^{\mathrm{a}}$ & 0.35 & $7 \cdot 31^{a}$ & 0.27 \\
\hline
\end{tabular}

CON, casein control diet; AC, bovine Achilles' tendon diet; AR, bovine artery diet.

a,b Mean values within a row with unlike superscript letters were significantly different $(P<0.05)$.

AC-fed group compared with the CON group. This may be another reason for the low total serum cholesterol level which was positively correlated with HMG-CoA reductase mRNA level in the AR-fed group $(r 0.742 ; P<0.01)$. The decrease in HMG-CoA reductase mRNA is surprising and conflicts with previous reports related to dietary fibre. Lund et al. (1993) and Moundras et al. (1997) have reported that dietary fibre increases hepatic reductase activity. The mechanism of reduction of HMG-CoA reductase activity might be due to the increased liver cholesterol concentration which may inhibit the hepatic HMG-CoA reductase mRNA level. In rats, most of the serum cholesterol $(60-80 \%)$ is transported in HDL and only 5-10\% in LDL, since they lack lipid transfer protein (Day et al. 1979). In contrast, the present study showed only $30 \%$ of serum cholesterol was from HDLcholesterol even in rats fed the 0.01 and $0.006 \%$ bovine dietary cholesterol diets. The dietary cholesterol level and $7 \%$ soyabean oil content with $0.4 \%$ plant sterols in the AIN 93G diet may be a reason for lower HDL-cholesterol concentration in the AC- and AR-fed groups. However, it has been shown that feeding normal Wistar-Furth or SpragueDawley rats with diets containing $1 \%$ cholesterol had negligible effects on serum cholesterol level (Ness \& Gertz, 2004).

The amino acid composition of animal protein might be an important factor affecting the behaviour of animal protein. The indigestible behaviour of animal protein may be due to the abundant collagen concentration, as Achilles' tendons and arteries contain high glycine and proline concentrations (Schubert et al. 1974). In addition, it has been suggested in previous studies that favourable amino acid composition is at least partially responsible for the suppressive effect on plasma cholesterol (Kayashita et al. 1995, 1997; Morita et al. 1997; Tomotake et al. 2000; Gudbrandsen et al. 2005). Lower methionine level or lower methionine:glycine (Table 2) ratio (80-85\%) in the AC and AR diets might have hindered the transfer of cholesterol from the liver into the bloodstream (Morita et al. 1997). In fact, the lower methionine level may reduce phosphatidyl choline synthesis via phosphatidyl ethanolamine, leading to the depression of apolipoprotein release into the circulation (Morita et al. 1997). Moreover, dietary arginine concentration was comparatively higher in AC and AR diets, which was negatively correlated with serum nonHDL-cholesterol level $(r 0.863 ; P<0.01)$ in a previous study (Eklund \& Sjoblom, 1980). These facts may suggest another mechanism of serum cholesterol lowering in the AR-fed group. On the other hand, the effect of methionine would give a reason for higher liver cholesterol levels in both the AC- and AR-fed groups. The liver cholesterol concentration was significantly higher in the AC-fed group, and tended to be higher in the AR-fed group, than that in the CON group. Han et al. (2003) also have reported that liver cholesterol concentration in groups fed the enzyme-resistant fractions of beans was significantly higher than in a cellulose powderfed group, although the reason for this remained unclear; however, it may be speculated that the increase in liver cholesterol concentration was due to an enhanced hepatic SR-B1 mRNA level. However, in the present study no significant difference was observed in SR-B1 mRNA level among groups. This finding does not agree with previous findings in mice showing that dietary fibres lower liver lipid concentration (Van Bennekum et al. 2005). However, the significantly higher liver cholesterol level in the AC-fed group may be a compensatory response to the higher sterol excretion compared with control.

The faecal cholesterol and coprostanol concentrations in the $\mathrm{AC}$ and $\mathrm{AR}$ groups were significantly higher than those in the CON group. Neutral sterols occupy a major part of steroid excretion, and it is noteworthy that the excretions of cholesterol and coprostanol were brought about by feeding AC and AR. This may be another reason for the lower serum cholesterol concentration in the AR-fed group. This was in agreement with findings for some dietary plant fibres (Kritchevsky et al. 1982; Eastwood, 1992; Moundras et al. 1997). Although the excretion of neutral sterols was affected by bovine protein, acid sterols were unaffected compared with casein. This was in contrast with previous findings showing that some plant fibres lower serum cholesterol by increasing cholesterol elimination as bile acids and neutral sterols (Fukushima et al. 2000; Buhman et al. 1998). Furthermore, Hara et al. (1998) reported that sugar-beet fibre reduces serum cholesterol level by reducing cholesterol synthesis in rats.

According to the results of dietary cholesterol intake, faecal sterol excretion and HMG-CoA reductase mRNA level, the sterol balance was 1.86-fold higher in the AC-fed group, and that in the AR-fed group was not different, compared with the control group. However, HMG-CoA reductase mRNA level in the AC-fed group was not significantly different compared with the control group and that in the AR-fed group was significantly lower relative to the control. In the present study, AC and AR diets may maintain the body sterol balance by two different mechanisms.

Serum TAG concentration was significantly lower in the AC- and AR-fed groups compared with the CON group. This was in agreement with previous findings showing that dietary fibres reduce serum TAG levels in rats $(\mathrm{Li}$ et al. 2004). Low TAG level in the AC- and AR-fed groups was accompanied by the reduction in FAS mRNA level in the animal protein-fed groups. In fact, the mRNA expression of FAS was significantly lower in the AR-fed group, and tended to be lower in the AC-fed group compared with the $\mathrm{CON}$ group. The FAS is a mutant enzyme complex that catalyses the synthesis of long-chain fatty acids from acetyl CoA and malonyl CoA (Wakil et al. 1983). Moreover, SREBP-1c mRNA level was significantly lower in the AR-fed group, and it tended to be lower in the AC-fed group compared with the CON group. The correlation between SREBP-1c and FAS was $r 0.660(P<0.01)$. It is suggested that the bovine protein-dependent decrease in FAS gene expression is due to the suppression of the gene expression of 
SREBP-1c, which is the transcriptional factor to generate FAS mRNA. SREBP are membrane-bound transcriptional factors which regulate the gene expression of enzymes in fatty acid and cholesterol biosynthesis (Brown \& Goldstein, 1997; Horton \& Shimomura, 1999). SREBP-1c preferentially enhances the transcription of genes required for fatty acid synthesis (Horton et al. 2002).

According to the results of the present study, the anaerobe bacteria population of the caecum in the AC- and AR-fed groups was significantly higher than that of the CON group. These results were accompanied by a higher faecal coprostanol concentration, which may be an index of the activity of intestinal flora (Arjmandi et al. 1992). It was suggested that protein was one of the major substrates for caecal fermentation in rats when an animal protein-based diet was fed (Tsukahara \& Ushida, 2000). Fatty acids of anaerobic bacteria are a major source of energy for the colonic mucosa in man (Roediger, 1980). The Bifidobacterium population was significantly higher in the AR-fed group, and tended to be higher in the AC-fed group compared with the CON group. In addition, the coliform bacteria population was significantly higher in the AC-fed group and tended to be higher in the AR-fed group than that in the CON group. However, there was no significant difference in caecal pool size of SCFA among the groups. The reason for higher bifidobacteria and coliform populations in the bovine protein-fed groups remains unclear. However, the undigested $\mathrm{AC}$ and $\mathrm{AR}$ proteins might be used as $\mathrm{N}$ sources by caecal bacteria.

In conclusion, the effects of some bovine proteins were most clearly seen when compared with rats fed casein. Bovine artery protein (AR) reduced the total serum cholesterol by reducing non-HDL-cholesterol, accompanied by lower HMG-CoA reductase mRNA level, and by increasing faecal neutral sterol excretion. Animal proteins, such as bovine Achilles' tendon protein and artery protein, reduced TAG concentration by reducing fatty acid synthesis in the liver accompanied by lower FAS mRNA level compared with the casein-fed group. In view of some of these facts, we conclude that some bovine animal proteins show dietary fibre-like properties by virtue of their low digestibility.

\section{Acknowledgements}

The present research was partially supported by a grant from the 21st Century COE Program (A-1), Ministry of Education, Culture, Sports, Science and Technology, Japan, and by Special Coordination Funds for Promoting Science and Technology (Leading Research Utilizing Potential of Regional Science and Technology) of the Japanese Ministry of Education, Culture, Sports, Science and Technology.

\section{References}

Anderson JW, Johnstone BM \& Cook-Newell ME (1995) Meta-analysis of the effects of soy protein intake on serum lipids. $N$ Engl $J$ Med 333, 276-282.

Arjmandi BH, Ahn J, Nathani S \& Reeves RD (1992) Dietary soluble fibre and cholesterol affect serum cholesterol concentration, hepatic portal venous short-chain fatty acid concentrations and faecal sterol excretion in rats. $J$ Nutr 122, 246-253.
Association of Official Analytical Chemists (1990) Official Methods of Analysis, $15^{\text {th }}$ ed, Arlington, VA: AOAC.

Brown MS \& Goldstein JL (1997) The SREBP pathway: regulation of cholesterol metabolism by proteolysis of a membrane-bound transcription factor. Cell 89, 331-340.

Buhman KK, Furumoto EJ, Domkin SS \& Story JA (1998) Dietary psyllium increases fecal bile acid excretion, total steroid excretion and bile acid biosynthesis in rats. J Nutr 128, 1199-1203.

Chomczynski P \& Sacchi N (1987) Single step method of RNA isolation by acid guandium thiocyanate-phenol-chloroform extraction. Anal Biochem 162, 156-159.

Day CE, Phillips WA \& Schurr PE (1979) Animal models for an integrated approach to the pharmacologic control of atherosclerosis. Artery 5, 90-96.

Eastwood MA (1992) The physiological effect of dietary fibre: an update. Апnи Rev Nutr 12, 19-35.

Eklund A \& Sjoblom L (1980) Effects of the source of dietary protein on serum lower density lipoprotein (VLDL + LDL) and tocopherol levels in female rats. $J$ Nutr 110, 2321-2335.

Erkkila AT \& Lichtenstein AH (2006) Fibre and cardiovascular disease risk: how strong is the evidence? J Cardiovasc Nurs 21, 3-8.

Folch J, Lees M \& Sloane Stanley JH (1957) A simple method for the isolation and purification of total lipides from animal tissues. $J$ Biol Chem 226, 497-509.

Fukushima M, Nakano M, Morii Y, Ohashi T, Fujiwara Y \& Sonoyama K (2000) Hepatic LDL receptor mRNA in rats is increased by dietary mushroom (Agaricus bisorpus) fibre and sugar beet fibre. J Nutr 130, 2151-2156.

Grundy SM, Ahrens EH Jr \& Miettinen TA (1965) Quantitative isolation and gas-liquid chromatographic analysis of total faecal bile acids. J Lipids Res 6, 397-410.

Gudbrandsen OA, Wergedahl H, Liaset B, Espe M \& Berge RK (2005) Dietary proteins with high isoflavone content or low methionine-glycine and lysine-arginine ratios are hypocholesterolaemic and lower the plasma homocysteine level in male Zucker fa/fa rats. Br J Nutr 94, 321-330.

Han KH, Fukushima M, Kato T, Kojima M, Ohba K, Shimada KI, Sekikawa M \& Nakano M (2003) Enzyme resistant fractions of beans lowered serum cholesterol and increased sterol excretions and hepatic mRNA levels in rats. Lipids 38, 919-924.

Hara H, Haga S, Kasai T \& Kiriyama S (1998) Fermentation products of sugar-beet fibre by cecal bacteria lower plasma cholesterol concentration in rats. $J$ Nutr 128, 688-693.

Hara H, Saito Y, Nakashima H \& Kiriyama S (1994) Evaluation of fermentability of acid-treated maize husk by rat caecal bacteria in vivo and in vitro. Br J Nutr 71, 719-729.

Horton JD, Goldstein JL \& Brown MS (2002) SREBPs: activators of the complete program of cholesterol and fatty acid synthesis in the liver. J Clin Invest 109, 1125-1131.

Horton JD \& Shimomura I (1999) Sterol regulatory element-binding proteins: activators of cholesterol and fatty acid biosynthesis. Curr Opin Lipidol 10, 143-150.

Jorgensen H, Zhao XQ, Theil PK, Gabert VM \& Bach Knudsen KE (2003) Energy metabolism and protein balance in growing rats fed different levels of dietary fibre and protein. Arch Tierernahr 57, $83-98$.

Kay RM (1982) Dietary fibre. J Lipid Res 23, 221-242.

Kayashita J, Shimaoka I \& Nakajoh M (1995) Hypocholesterolemic effect of buckwheat protein extract in rats fed cholesterol enriched diets. Nutr Res 15, 691-698.

Kayashita J, Shimaoka I, Nakajoh M, Yamazaki M \& Kato N (1997) Consumption of buckwheat protein lowers plasma cholesterol and raises faecal neutral sterols in cholesterol-fed rats because of its low digestibility. J Nutr 127, 1395-1400.

Khosla K, Samman S \& Carrol KK (1991) Decreased receptormediated LDL catabolism in casein-fed rabbits precedes the increase in plasma cholesterol levels. J Nutr Biochem 2, 203-209. 
Kritchevsky D, Tepper SA, Czarnecki SK \& Klurfeld DM (1982) Atherogenicity of animal and vegetable protein. Influence of the lysine to arginine ratio. Artherosclerosis 41, 429-431.

Lairon D, Arnault N, Bertrais S, Planells R, Clero E, Hercberg S \& Boutron-Ruault MC (2005) Dietary fibre intake and risk factors for cardiovascular disease in French adults. Am J Clin Nutr 82, $1185-1194$.

Li J, Wang J, Kaneko T, Qin LQ \& Sato A (2004) Effects of fibre intake on the blood pressure, lipids, and heart rate in Goto Kakizaki rats. Nutrition 20, 1003-1007.

Lund EK, Salf KL \& Johnson IT (1993) Baked rye products modify cholesterol metabolism and crypt cell proliferation rates in rats. J Nutr 123, 1834-1843.

Matsubara Y, Sawabe A \& Iizuka Y (1990) Structures of new linoroid glycosides in lemon (Citrus limon Burm.f.) peelings. Agric Biol Chem 54, 1143-1148.

Mitsuoka T, Ohno K, Benno Y, Suzuki K \& Namba K (1976) The fecal flora of man IV. Communication: Comparison of the newly developed method with the old conventional method for the analysis of intestinal flora (article in German). Zentralbl Bakteriol (Orig A) 234, 219-233.

Mitsuoka T, Sega T \& Yamamoto S (1964) Ein neur Slektivnahrboden für Bacteroides (A new selective medium for bacteroides). Zentralbl Bakteriol (Orig) 195, 69-79.

Mitsuoka T, Sega T \& Yamamoto S (1965) Eine verbesserte Methodic der qualitativen und quantitativen Analyse der Darmflora von Menschen und Tieren (Improved methodology of qualitative and quantitative analysis of the intestinal flora of man and animals). Zentralbl Bakteriol (Orig) 195, 455-469.

Morita T, Oh-hashi A, Takei K, Ikai M, Kasaoka S \& Kiriyama S (1997) Cholesterol-lowering effects of soybean, potato and rice proteins depend on their low methionine contents in rats fed a cholesterol free purified diet. J Nutr 127, 470-477.
Moundras C, Behr SR, Remesy C \& Demigne C (1997) Faecal losses of sterols and bile acids induced by feeding rats guar gum due to greater pool size and liver bile acid secretion. $J$ Nutr 127, 1068-1076.

National Research Council (1985) Guide for the Care and Use of Laboratory Animals. National Institutes of Health Publication. Washington, DC: National Academy of Sciences, no. 85-23, revised ed.

Ness GC \& Gertz KR (2004) Hepatic HMG-CoA reductase expression and resistance to dietary cholesterol. Exp Bio Med (Maywood) 229, 410-414.

Roediger WEW (1980) Role of anaerobic bacteria in the metabolic welfare of the colonic mucosa in man. Gut 21, 793-798.

Schubert D, Harris AJ, Devine CE \& Heinemann S (1974) Characterization of a unique muscle cell line. J Cell Biol 61, 398-413.

Sorci-Thomas M, Wilson MD, Johnson FL, Williams DL \& Rudel LL (1989) Studies on the expression of genes encoding apolipoproteins B100 and B48 and the low density lipoprotein receptor in non human primates. J Biol Chem 264, 9039-9045.

Tomotake H, Shimaoka I, Kayashita J, Yokoyama F, Nakajoh M \& Kato N (2000) A buckwheat protein product suppresses gallstone formation and plasma cholesterol more strongly than soy protein isolate in hamsters. $J$ Nutr 130, 1670-1674.

Tsukahara T \& Ushida K (2000) Effects of animal protein diets on caecal fermentation in guinea pigs (Cavia porcellus), rats (Rattus norvegicus) and chicks (Gallus gallus domesticus). Comparative Biochemistry and Physiology 127A, 139-146.

Van Bennekum AM, Nguyen DV, Schulthess G, Hauser H \& Phillips MC (2005) Mechanisms of cholesterol-lowering effects of dietary insoluble fibres: relationships with intestinal and hepatic cholesterol parameters. Br J Nutr 94, 331-337.

Wakil SJ, Stoops JK \& Joshi VC (1983) Fatty acid synthesis and its regulation. Апnu Rev Biochem 52, 537-579. 